\title{
ERRATUM
}

\section{ESRP1 is overexpressed in ovarian cancer and promotes switching from mesenchymal to epithelial phenotype in ovarian cancer cells}

HM Jeong, J Han, SH Lee, H-J Park, HJ Lee, J-S Choi, YM Lee, Y-L Choi, YK Shin and MJ Kwon

Oncogenesis (2017) 6, e391; doi:10.1038/oncsis.2017.89; published online 20 November 2017

Correction to: Oncogenesis (2017) 6, e389; doi:10.1038/ oncsis.2017.87; Published online 9 October 2017

The legend of Figure 5 was published incorrectly. The correct legend should read as follows:

Figure 5. Association between ESRP1 gene expression and OS or PFS in patients with ovarian serous adenocarcinoma. (a, b) Kaplan-Meier plot of 5-year OS, and PFS in total primary tumors and $(\mathbf{c}, \mathbf{d})$ stage III primary tumors. Patients were divided into two groups based on ESRP1 expression, ESRP1 low expression (ESRP1low) and ESRP1 high expression (ESRP1-high) groups. The statistical difference in the survival between the two groups was tested with the log-rank test. The number of patients for each group is provided in parentheses.
This error has now been rectified and the corrected article appears in this issue together with this corrigendum.

The publishers wish to apologise for any inconvenience caused.

Oncogenesis is an open-access journal published by Nature Publishing
Group. This work is licensed under a Creative Commons Attribution 4.0
International License. The images or other third party material in this article are included
in the article's Creative Commons license, unless indicated otherwise in the credit line; if
the material is not included under the Creative Commons license, users will need to
obtain permission from the license holder to reproduce the material. To view a copy of
this license, visit http://creativecommons.org/licenses/by/4.0/

(c) The Author(s) 2017 